\section{EXPLANATION OF GUIDELINES}

\begin{abstract}
Why proposals can not be submitted via email:Proposal forms are designed to facilitate efficient entry of information into the database. Even when the order of an email proposal follows the form, data entry is slowed because the information does not appear in the same place spatially as on the form. Time is too critical a resource during the proposal processing phase to spend on deciphering e-mail proposals and on making the required second and third copies.
\end{abstract}

Why proposals can not be submitted by fax:Faxed proposals are difficult, sometimes impossible, to read.

Why single presentations are favored: Single presentations allow for more participation by more people at the meeting. This is especially helpful for younger scholars and for those making their first conference presentation.

Why only one proposal should be submitted for presentation:The first proposal received by the ASA Executive Office will be the proposal of record. Additional proposals--either individual or as part of a constituted panel--will not be processed.

Requesting AN equipment: AN equipment requests must be made at the time proposals are submitted. Failure to request A/V equipment will result in the individual having to rent the equipment themselves. This is because the Secretariat uses the AN request on the proposal form to negotiate an AN contract and to schedule those room that will be set aside for AN use. Essentially, when an AN request is made on the proposal form, rooms can be scheduled so that equipment set-up, rental, and tear down costs to the ASA are as low as possible. When AN equipment is requested late, that piece of equipment carries a separate set-up, rental and tear-down cost that the ASA will not pay, since it defeats the purpose of early planning to minimize costs.

Procedures concerning late A/V request: Persons requesting AN equipment after March 15, 2002 will be referred to the on-site $A N$ vendor where that person or persons will make arrangements to secure their equipment request.

Type of A/V Equipment provided by ASA: The ASA provides to conference participants--at absolutely no charge to them-- three different items of AV equipment (slide projectors, overhead projectors, and VCRs), provided this equipment is requested on the proposal form. The ASA provides the same items of A $N$ equipment for poster session presenters. They are also provided with chalkboard and corkboard.

Why "unreviewed status" should be stipulated on proposal forms: Sponsored organizations are allowed up to two unreviewed panels per conference. Persons submitting the proposals should not only designate the panels as sponsored by that particular organization but they have unreviewed status as well. Since panels may be listed in the program as "organized under the auspices of ...," merely identifying a proposal as being from a sponsored organization does not confer unreviewed status upon it.

What are the consequences of a delinquent payment status: Delinquent payment status will affect the consideration of proposals. Proposals of persons that have not paid their membership dues and preregistration fees for the current year will not be processed. Additionally, a panel or roundtable proposal containing one or more delinquent persons will not be processed.

Why a section must be designated: Proposals that have section designations will be seen by the relevant Panels Committee members at the earliest possible time. If your proposal does not fit into one of the thematic section, designate section $Z$. Proposals that have no designation will have to await a decision as to their disposition. Providing no designation at all jeopardizes your chances for full and early consideration.

\section{CONOVER PORTER AWARD}

The Africana Librarians Council of the African Studies Association seeks nominations for the twelfth biennial Conover-Porter Award for excellence in Africana bibliography or reference work. Any Africa-related reference work, bibliography or bibliographic essay, regardless of format, published separately or as part of a larger work during 1999, 2000 or 2001 can be nominated for the 2002 award. The award includes a prize of $\$ 300$ that will be presented during the 2002 annual meeting of the African Studies Association in Washington, D.C. Nominations must be received by January 31, 2002 . Please include a brief justification and at least one review.

Helen Conover was senior bibliographer in the African Section of the Library of Congress, serving 32 years before her retirement in 1963. Dorothy Porter Wesley was librarian of the Moorland-Springarn Research Center, Howard University, retiring in 1973 after 45 years of service.

The first award in 1980 was presented to Julian Witherell for his The United States and Africa: Guide to the U.S. Official Documents and Government-Sponsored Publications on Africa, 1785-1975 (Washington: Library of Congress, 1978). Winner of the award in 2000 was John Middleton (ed. in chief): Encyclopedia of Africa South of the Sahara. (New York: Charles Scribner's Sons, 1997).

A list of additional Conover-Porter winners, as well as a copy of the form for submitting nominations for Conover-Porter 2002, may be found on the Africana Librarians Council Web site at http://lcweb.loc.gov/rr/amed/conport2.html.

Please send nominations to or request further information from: Kenneth $P$. Lohrentz, 320 Anschutz Library, University of Kansas Libraries, 1301 Hoch Auditoria Dr., Lawrence, KS., 66045-7537, USA (phone 785-864-4593, fax 785-864-5705, e-mail klohrentz@ukans.edu).

\section{PAPER CALENDAR}

\section{OHIO UNIVERSITY's INSTITUTE FOR THE African CHILD}

Submissions are invited for an edited volume entitled HIVIAIDS and African Children: Health Challenges and Educational Possibilities. HIVIAIDS and African Children: Health Challenges and Educational Possibilities is edited by the Ohio University's Institute for the African Child and will be published by the Research in International Studies of the Ohio University Press. Full-length chapters $(6,000$ to 7,000 words) and shorter casestudies (1,000 to 2,500 words) are invited from both scholars and practitioners. The deadline for submissions is April 1, 2002. For further information contact the volume editors: Arvind Singhal, Tel: (740) 5934903; Fax: (740) 593-4810; Email: singhal@ohio.edu or W. Stephen Howard, Tel: (740) 593-1834; Fax: (740) 593-1837; Email: howard@ohio.edu; Website: ohiou.edu/Toguna; ohiou.edu/oupress. 